\title{
Canine visceral leishmaniasis: a remarkable histopathological picture of one asymptomatic animal reported from Belo Horizonte, Minas Gerais, Brazil
}

\author{
[Leishmaniose visceral canina: um caso inusitado de um animal assintomático proveniente \\ de Belo Horizonte, Minas Gerais] \\ S.C. Xavier ${ }^{1}$, I.M. Chiarelli ${ }^{1}$, W.G. Lima $^{2}$, R. Gonçalves ${ }^{1}$, W.L. Tafuri ${ }^{2}$ \\ ${ }^{1}$ Escola de Veterinária - UFMG \\ ${ }^{2}$ Instituto de Ciências Biológicas - UFMG \\ Caixa Postal 486 \\ 31270-901 - Belo Horizonte, MG
}

\begin{abstract}
A remarkable histopathological picture of one asymptomatic dog naturally infected with Leishmania infantum (syn. chagasi) has been presented. Intracellular parasites were ease found in macrophages of all exanimated organs, especially in skin. Embedded paraffin tissues of liver, spleen, axillary and popliteal lymph nodes, and skin (ear, muzzle and abdomen) were stained by hematoxylin and eosin and by immunocytochemical reaction (streptoavidin-peroxidase method) to detect parasites. All organs showed an intense parasitism associated to severe pathological changes. All lymph nodes had conspicuous histological architecture alterations. Lymphocytes were replaced by macrophages stuffed with an intense number of amastigotes forms of Leishmania. The lymphoid nodules (without germinal centers) and the mantle zones in the cortex that surround the follicles were markedly attenuated. Livers showed small intralobular granulomas composed by macrophages loaded with amastigotes. Spleens had an intense depression of the white pulp whereas the lymphocytes were replaced by parasitized macrophages. All fragments of different anatomical region of skin (ear, muzzle and abdomen) showed a diffuse chronic inflammation. The cellular exudate was composed by macrophages, plasmocytes and lymphocytes. Macrophages loaded with amastigotes were ease found in all tissue fragments, but more intense in ear and muzzle. Thus, this fact enhances the importance of asymptomatic dogs in the epidemiology of visceral leishmaniasis.
\end{abstract}

Keywords: dog, Leishmania infantum, histopathology

\section{RESUMO}

Relata-se um quadro histológico caracterizado por lesões acentuadas em tecidos de um cão assintomático naturalmente infectado por Leishmania infantum (sin. chagasi). Cortes parafinados de figado, baço, linfonodos (cervical, axilar e popliteo) e pele (orelha, espelho nasal e abdome) foram corados pela técnica de hematoxilina-eosina e pela técnica imunoistoquímica de estreptoavidina-peroxidase para deteç̧ão de formas amastigotas de Leishmania. Os linfonodos apresentaram profundas alterações estruturais. Em todos observouse depleção linfocitária, principalmente da córtex, com substituição dos linfócitos por macrófagos abarrotados de formas amastigotas de Leishmania. No figado, observou-se a presença de pequenos granulomas intralobulares compostos por macrófagos intensamente parasitados, plasmócitos e raros linfócitos. No baço, a alteração marcante foi a depressão da polpa branca. Os folículos linfóides foram substituídos por macrófagos intensamente parasitados com as formas amastigotas de Leishmania. Fragmentos de pele de orelha, espelho nasal e abdome apresentaram reação inflamatória crônica e difusa com exsudato celular composto por macrófagos, plasmócitos e linfócitos. Parasitos foram detectados em todos os tecidos estudados e mais numerosos na pele da orelha e focinho. Os achados mostram a importância de cães assintomáticos na epidemiologia da leishmaniose visceral.

Palavras-chave: cão, Leishmania infantum, histopatologia

Recebido em 15 de março de 2005

Aceito em 3 de março de 2006

*Autor para correspondência (corresponding author)

E-mail: wagner@icb.ufmg.br

Apoio: FAPEMIG (CDS 2263-97; EDT-2124/03) e CNPq (Processo nº 472287/2001) 


\section{INTRODUCTION}

Human visceral leishmaniasis (HVL) and canine visceral leishmaniasis (CVL) in the New World are caused by intracellular protozoan Leishmania infantum (syn. L.chagasi) (Maurício et al., 2000) which is transmitted by the bite of an infected phlebotomine Lutzomyia (Lutzomyia) longipalpis. Following injection into the skin, the extracellular promastigote form of the parasite must rapidly enter its host cell, the macrophage, and later transform into the intracellular amastigote form. Visceral leishmaniasis (VL) remains a serious public health problem in the world and dogs (Canis familaris) are the main peridomestic reservoir host (Anderson, 1980; Grimaldi et al., 1989; Tesh, 1995).

In Brazil, VLC is highly endemic in the semiarid northeastern states of Ceará, Bahia, Maranhão, Piauí, Pernambuco, Rio Grande do Norte and Paraíba. In all states there is an association with infected dogs and abundant L. longipalpis (Deane and Deane, 1962; Guedes et al., 1978). The CVL appears to be spreading further in Brazil and outbreaks have been reported in metropolitan cities as Belo Horizonte, MG (Genaro et al., 1988; Michalick et al., 1993), Teresina, PI, São Luiz, MA, Fortaleza, CE, Rio de Janeiro, RJ (Marzochi et al., 1994) and Salvador, BA (Cunha et al., 1995; Ashford et al., 1998).

The skin is considered the more important tissue reservoir of parasites in healthy and sick Leishmania-infected dogs (Abranches et al., 1991; Solano-Gallego et al., 2001; SolanoGallego et al., 2004). Thus, the presence of Leishmania especially in the skin of dogs without clinical signs enhances the importance of asymptomatic dogs in the epidemiology of visceral leishmaniasis. The present study describes a remarkable pathological picture of one asymptomatic dog naturally infected with Leishmania infantum.

\section{MATERIAL E METHODS}

An asymptomatic infected mongrel dog was detected by an epidemiological survey of canine visceral leishmaniasis in Belo Horizonte, Minas Gerais. This inquire is based on a serological survey of canine population by anti-antigen
(Leishmania) indirect immunofluorescence (IFAT), complement fixation reaction (CFR) test (Pellegrino and Brener, 1958) and enzyme-linked immunosorbent assay (ELISA).

The animal was considered asymptomatic dog without the classical symptoms of the disease as weight loss, clinical anaemia (pale mucous eye membrane), generalized lymphadenopathy, onycogryphosis and cutaneous lesions (dry exfoliative dermatitis, alopecia and scars).

The parasites were previously classified as $L$. infantum (syn. chagasi) to a complex level by PCR using conserved regions of kinetoplastidae and hybridization with kDNA probes to complex (Tafuri et al., 2001).

The dog was sacrificed with an overdose of Thiopental sodic $(33 \%, 5 \mathrm{ml} / \mathrm{kg}$ dose, IV). Tissue samples of liver, spleen, cervical, axillary and popliteal lymph nodes and skin (ear, nose and abdomen) were carried out and Giemsa staining was used to visualize amastigotes forms of Leishmania by optical microscope using oil immersion (objective 100x).

Samples of liver, spleen, cervical, axillary and popliteal lymph nodes and skin (ear, muzzle and abdomen) were fixed in $10 \%$ buffered formalin solution, embedded paraffin sections wires stained with hematoxilin and eosin.

Others paraffin tissue samples $(0,5 \times 0,5 \mathrm{~cm})$ were stained by biotin-streptoavidin peroxidase immunostainning method to detect amastigotes forms of Leishmania (Silva et al., 2002; Tafuri et al., 2004).

\section{RESULTS}

During the necropsy no gross important lesions were showed show in any examined organs. However, under optic microscopical analysis, a conspicuous histopathological picture was observed. It was characterized by an intense parasitism with disruption of the architecture of the cervical, axillary and popliteal lymph nodes. Also, a chronic inflammatory reaction with parasites was noted in all organs, as described as follows. 
Liver: a remarkable leishmaniotic chronic granulomatous inflammatory reaction was observed distributed on all tissue sections (Tafuri et al., 1996; Tafuri et al., 2001). In fact, various intralobular granulomas could be noted and they were constituted by macrophages, loaded with amastigotes forms of Leishmania, some epithelioid cells, small numbers of lymphocytes, plasmocytes and rare neutrophils. The intralobular granuloma formations, localized in the sinusoid lumen, were very small and rarely confluent. Moreover brown crystals (hemossiderin) were detected chiefly in kupffer cells and in macrophages within granulomas (Fig.1a,b)

Lymph nodes: all lymph nodes (cervical, axillary and popliteal) showed a conspicuous change in its architecture. Lymphocytes were replaced by many macrophages loaded with various amastigotes forms of Leishmania. The lymphoid nodules (without germinal centers) and the cortical region were markedly attenuated. In resume, the histological analysis showed lymphocytes and follicular structures replaced or obscured by proliferation of macrophages loaded with amastigotes forms of Leishmania (Fig. 2a,b).

Spleen: a dramatic white pulp depletion was observed and lymphocytes were replaced by macrophages loaded with amastigotes. The white pulps were restricted to a few lymphocytes around the central arteriole. The red pulp showed profound distortion due to the marginal macrophage proliferation. Macrophages were organized in granulomas and they were loaded with parasites and with brown crystals of hemossiderin. An intense parasitism was also observed in the thick capsule, subcapsular and trabecular system (Fig. 3).

Skin: the various skin samples from the ears, muzzle and abdominal regions showed focal chronic inflammation. The cellular exudate was observed around the small vessels and glands appendage in the deep dermis and also diffuses in the upper dermis. The inflammatory cells were macrophages, plasmocytes and lymphocytes. Many amastigotes forms of Leishmania could be found inside macrophages in all skin, but the parasitism was more intense in ears and muzzles skin sections (Fig. 4a,b,c).

\section{DISCUSSION}

Classical canine leishmaniasis appears as a chronic wasting disease with anaemia, generalized lymphadenopathy, hepatesplenomegaly, onycogryphosis and cutaneous lesions (dry exfoliative dermatitis, ulcerations and alopecia). (Slappendel and Greene,1990; Ferrer, 1991; González et al., 1990; Ciaramella et al., 1997). The main histopathological alteration is a hypertrophy and hyperplasia of the monocyte-mononuclear system mostly of spleen, lymph nodes, liver and bone-marrows. Other lesions have been also observed as a chronic dermatitis (Tafuri et al., 1996; Fondevila et al., 1997; Ferrer et al., 1999); granulomatous inflammatory reactions in livers and spleens (Tafuri et al., 1996); interstitial pneumonitis (Duarte et al., 1986; Gonçalves, 2003) and glomerulonephritis with or without nephrotic syndrome (Tafuri et al.,1989; Nieto et al., 1992; Font and Closa, 1997).

Some reports from Mediterranean area have described a high prevalence of infection in dogs, demonstrated by a specific humoral and cellular immunity and leishmanial DNA detection. These investigations showed that in an endemic region there is a large population of Leishmaniainfected but clinically healthy dogs and a smaller proportion of dogs with clinically patent leishmaniosis (Cabral et al., 1998; SolanoGallego et al., 2001).

Thus, the histopathological picture observed in this case could be indicated that asymptomatic dogs can have parasites in all superficial lymph nodes and in liver, spleen and skin. This later fact enhances the importance of asymptomatic dogs in the epidemiology chain of visceral leishmaniasis as discussed by Abranches et al. (1998) in Portugal and Solano-Galeno et al. (2004) in Spain. Solano-Galeno et al. (2004) showed that is possible detect sick dogs with normal skin, but harboring parasites as well. Taken together these ideas and this present case, we could say that asymptomatic dogs probably play an important role in the transmission of leishmaniasis. 

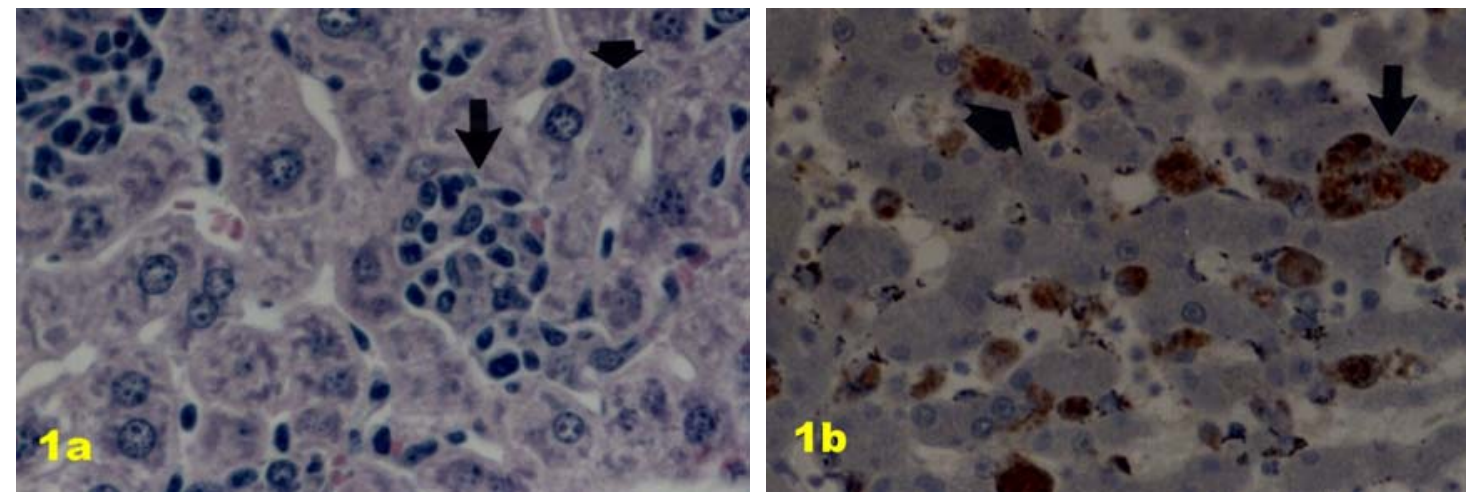

Figure 1. Liver section of asymptomatic dog. a) Observe an intralobular granuloma formation (arrow) and kupffer cells loaded with amastigotes of Leishmania (arrowhead); HE 440x. b) Many immunolabelled amastigotes could be seen in granulomas macrophages (arrow) and inside of kupffer cells (arrowheads); Streptoavidin-peroxidase, 440x.
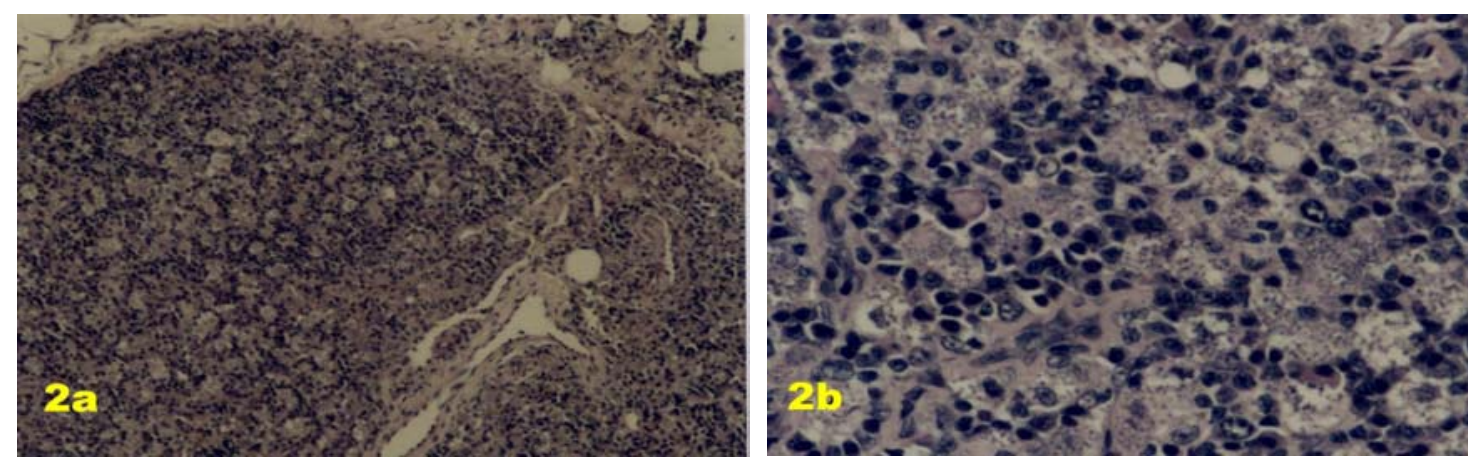

Figure 2. Popliteal lymph nodes section of asymptomatic dog. a) Lymphoid nodules and the mantle zones in the cortex that surround the follicles were markedly attenuated; HE 40x. b) High magnification showing macrophages stuffed with amastigotes of Leishmania; HE 440x.

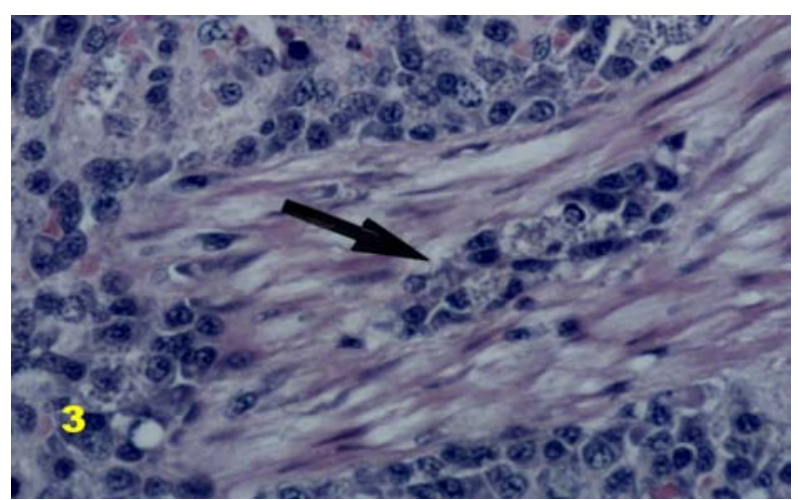

Figure 3. Spleen section of asymptomatic dog. Red pulp showing an intense macrophages proliferation loaded with amastigotes of Leshmania; note intracellular parasites in the spleen trabecular system (arrows); HE 440x. 

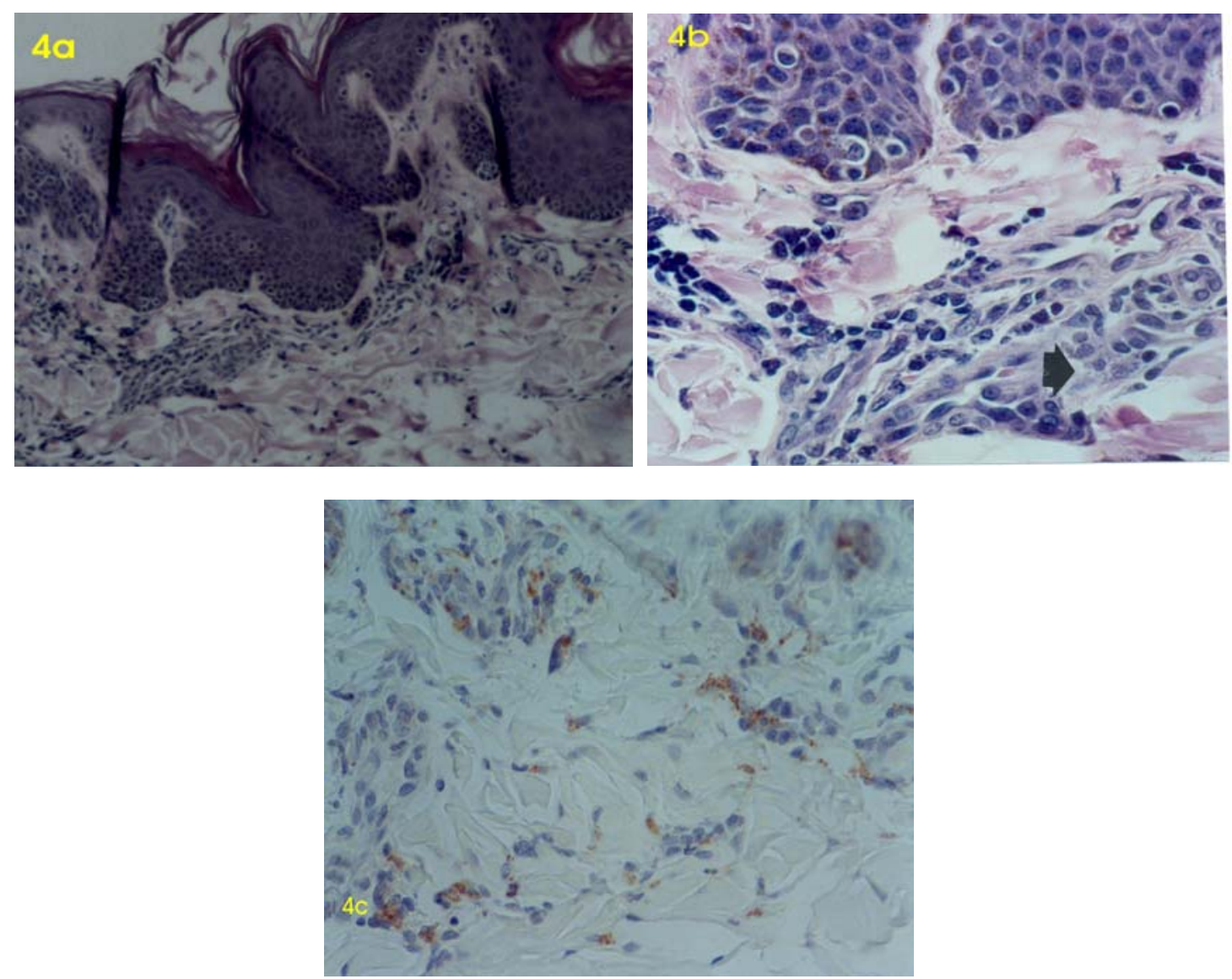

Figure 4. Muzzle section of asymptomatic dog. a) Inflammatory cellular exudate could be noted in upper and deep dermis; HE40x. b) Higher magnification showing inflammatory macrophages intensely parasitized with Leishmania (arrowheads); HE 440x. c) Immunolabelled parasites are easily found inside macrophages in the dermis; streptoavidin-peroxidase, 440x.

\section{REFERENCES}

ABRANCHES, P.; CAMPINO, L.; SANTOSGOMES G.M. Leishmaniose canina: novos conceitos de epidemiologia e imunopatologia e seus reflexos no controlo da leishmaniose visceral humana. Acta Med. Port., v.11, p.871$875,1998$.

ABRANCHES, P.; SANTOS-GOMES, G.; RACHAMIM, N. et al. An experimental model for canine leishmaniasis. Parasitol. Immunol., v.13, p.537-550, 1991.

ANDERSON, D.C.; BUCKNER, R.G.; GLENN, B.L. et al. Endemic canine leishmaniasis. Vet. Pathol., v.17, p.94-96, 1980.

ASHFORD, D.A.; DAVID, J.R.; FREIRE, M. et al. Studies on control of visceral leishmaniasis: impact of dog control on canine and human visceral leishmaniasis in Jacobina, Bahia, Brazil. Am. J. Trop. Med. Hyg., v.59, p.53-57, 1998.

CABRAL, M.; O'GRADY, J.E.; GOMES, S. et al. The immunology of canine leishmaniosis: strong evidence for a developing disease spectrum from asymptomatic dogs. Vet. Parasitol., v.76, p.173-180, 1998.

CIAMARELLA, P.; OLIVA, G.; LUNA, R.D.; et al. A retrospective clinical study of canine leishmaniasis in 150 dogs naturally infected by Leishmania infantum. Vet. Rec., v.22, p.539-543, 1997.

CUNHA, S.; FREIRE, M.; EULALIO, C. et al. Visceral leishmaniasis in a new ecological niche near a major metropolitan area of Brazil. Trans. R. Soc. Trop. Med. Hyg., v.89, p.155-158, 1995. 
DEANE, L.M.; DEANE, M.P.Visceral leishmaniasis in Brazil. Geographical distribution and transmission. Rev. Inst. Med. Trop. São Paulo, v.4, p.149-212, 1962.

DUARTE, M.I.S.; LAURENTI, M.D.; NUNES, V.L.B. et al. Intersticial pneumonitis in canine visceral leishmaniasis, Rev. Inst. Med. Trop. São Paulo, v.28, p.431-436, 1986.

FERRER, L. Clinical aspects of canine leishmaniasis. In: INTERNATIONAL CANINE LEISHMANIASIS FORUM, 1999, Barcelona. Proceedings... Barcelona, 1999. p.6-10.

FERRER, L.; JUANOLA, B.; RAMOS, J.A. et al. Chronic colitis due to Leishmania infection in two dogs. Vet. Pathol., v.28, p.342-343, 1991.

FONDEVILA, D.; VILAFRANCA, M.; FERRER, L. In conclusion, the results of the present study cast doubt on the relevance of infected but symptomless dogs in the epidemiology of canine leishmaniosis. Vet. Immunol. Immunopathol., v.56, p.319-327, 1997

FONT, A.; CLOSA, J.M. Ultrasonographic localization of a caudal vena cava thrombus in a dog with leishmaniasis. Vet. Radiol. Ultrasound., v.38, p.394-3966, 1997.

GENARO, O.; MAYRINK, W.; MICHLICK, M.S.M. et al. Naturally occoring visceral leishmaniasis in dogs: clinical aspects. Mem. Inst. Oswaldo Cruz, v.83, p.43, 1988.

GONÇALVES, R.; TAFURI, W.L.; MELO, M.N. et al. Chronic interstitial pneumonitis in dogs naturally infected with Leishmania (Leishmania) chagasi - histopathological and morphometrical study. Rev. Inst. Med. Trop. São Paulo, v.45, p.1-12, 2003.

GONZÁLEZ, J.L.; FERMIN, M.L.; GARCIA, P.et al. Erosive colitis in experimental canine leishmaniasis. J. Vet. Med. B, v.37, p.377-382, 1990 .

GRIMALDI, G.; TESH, R.B.; Mc MATHONPRATT, D.A. A review of the geografic distribution and epidemiology of leishmaniasis in the New World. Am. J. Trop. Med. Hyg., v.41, p.687-725, 1989.

GUEDES, G. E.; MAROJA, A.; CHAVES, E. et al. Calazar no litoral do estado da Paraíba, Brasil. Encontro de 70 casos humanos e 16 caninos. Rev. Inst. Med. Trop., v.16, p.265-600, 1978.
MARZOCHI, M.C.; MARZOCI, K.B.F.; CARVALHO, R.W. Visceral Leishmaniasis in Rio de Janeiro. Parasitol. Today, v.10, p.37-40, 1994.

MAURÍCIO I.L.; STOTHART J.R.; MILES, M.A. The strange case of Leishmania chagasi. Parasitol. Today, v.16, p.188-189, 2000.

MICHALICK, M.S.M. Spreading of visceral leishmaniasis in urban area of Belo Horizonte, MG, Brazil. Mem. Inst. Oswaldo Cruz. v.88, supl. 1, p.53, 1993.

NIETO, C.G.; NAVARRETE, I.; HABELA, M.A. et al. Pathological changes in kidneys of dogs with natural Leishmania infection. Vet. Parasitol., v.45, p.33-47, 1992.

PELLEGRINO, J.; BRENER, Z. Reação de fixação de complemento com sangue dessecado no diagnóstico do calazar canino. Rev. Bras. Malariol. Doenças Trop. Publ. Avulsas, v.10, p.39-44, 1958.

SILVA, F.L.; TAFURI, W.L.; OLIVEIRA, M.R. et al. Histopathological and immunohistochemical study of the gastrointestinal tract from a dog naturally infected with Leishmania (Leishmania) chagasi. Arq. Bras. Med. Vet. Zootec., v.54, p.340-344, 2002.

SLAPPENDEL, R. J.; GREENE, C. E. Leishmaniasis. In: GREENE, C. E. Infectious diseases of the dog and cat. Filadélfia: W. B. Saunders, 1990. p.769-777.

SOLANO-GALLEGO, L.; FERNANDEZBELLON, H.; MORELL, P. et al. Histological and immunohistochemical study of clinically normal skin of leishmania infantum-infected Dogs. J. Comp. Pathol., v.130, p.7-12, 2004.

SOLANO-GALLEGO, L.; MORELL, P.; ARBOIX, M. et al. Prevalence of Leishmania infantum infection in dogs living in an area of canine leishmaniasis endemicity using PCR on several tissues and serology. J. Clin. Microbiol., v.39, p.560-563, 2001.

TAFURI, W.L.; MICHALICK, M.S.; DIAS, M. et al. Optical and electron microscopic study of the kidney of dogs naturally and experimentally infected with Leishmania (Leishmania) chagasi. Rev. Inst. Med. Trop. São Paulo, v.3, p.139-145, 1989. 
TAFURI, Wg. L.; OLIVEIRA, M.R.; MELO, M.N. et al. Canine visceral leishmaniosis: a remarkable histopathological picture of one case reported from Brazil. Vet. Parasitol., v.96, p.203-212, 2001.

TAFURI, Wg. L.; TAFURI, W.L.; BARBOSA, A.J.A. et al. Histopathology and immunocytochemical study of type 3 and 4 complement receptors in the liver and spleen of dogs naturally and experimentally infected with Leishmania (Leishmania) chagasi. Rev. Inst. Med. Trop. São Paulo, v.38, p.81-89, 1996.

TESH, R.B. Control of zoonotic visceral leishmaniasis: Is it time to chance strategies? $\mathrm{Am}$. J. Trop. Hyg., v.52, p.287-292, 1995. 